INTER NATIONAL MONETARY FUND
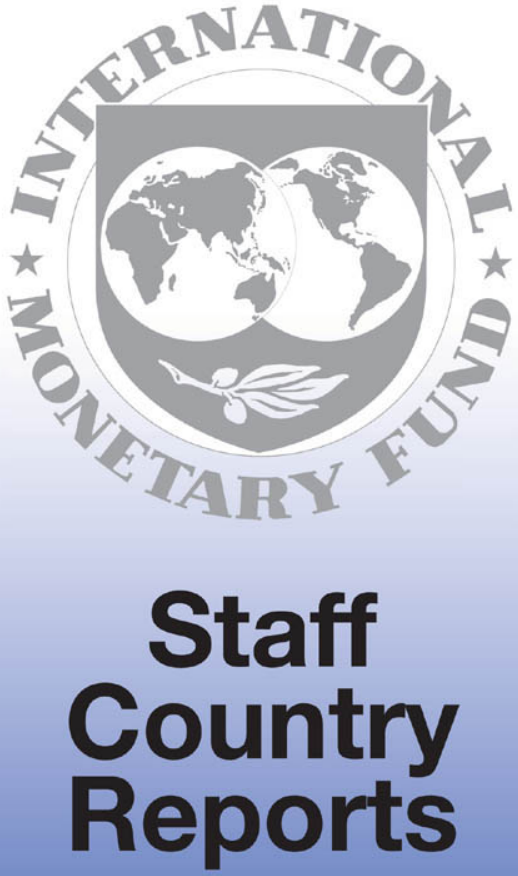


\title{
Belize: Use of Fund Resources—Request for Emergency Assistance—Staff Report; Press Release on the Executive Board Discussion; and Statement by the Executive Director for Belize
}

In the context of the use of Fund resources - request for emergency assistance for Belize, the following documents have been released and are included in this package:

- $\quad$ The staff report for the Use of Fund Resources - Request for Emergency Assistance, prepared by a staff team of the IMF, following discussions that ended on January 22, 2009, with the officials of Belize on economic developments and policies. Based on information available at the time of these discussions, the staff report was completed on February 3, 2009. The views expressed in the staff report are those of the staff team and do not necessarily reflect the views of the Executive Board of the IMF.

- $\quad$ A Press Release summarizing the views of the Executive Board as expressed during its February 18, 2009 discussion of the staff report that completed the request.

- $\quad$ A statement by the Executive Director for Belize.

The document listed below has been separately released.

Letter of Intent sent to the IMF by the authorities of Belize*

*Also included in Staff Report

The policy of publication of staff reports and other documents allows for the deletion of market-sensitive information.

\author{
Copies of this report are available to the public from \\ International Monetary Fund • Publication Services \\ $70019^{\text {th }}$ Street, N.W. • Washington, D.C. 20431 \\ Telephone: (202) 623-7430 • Telefax: (202) 623-7201 \\ E-mail: publications@imf.org Internet: http://www.imf.org
}

\section{International Monetary Fund Washington, D.C.}


This page intentionally left blank 
INTERNATIONAL MONETARY FUND

BELIZE

Use of Fund Resources-Request for Emergency Assistance

Prepared by the Western Hemisphere Department

Approved by Gilbert Terrier and Alan MacArthur

February 3, 2009

- Belize suffered considerable damage from two tropical systems during the 2008 hurricane season. Tropical storm Arthur in late May and heavy rains from a tropical depression in late October resulted in massive flooding across Belize and loss of lives and property. Damage to housing and infrastructure together with losses of output and export earnings and increases in imports, are estimated at 4.8 percent of GDP.

- The reconstruction effort, which involves a reallocation of public investment, is supported by external assistance. The government is seeking loans form the CDB (US\$10 million) and the IDB (US\$5 million) in support of infrastructure rehabilitation projects and has reassigned budgetary funds for this purpose.

- The authorities have made a request for a purchase under the Fund's policy on Emergency Assistance for Natural Disasters (ENDA) equivalent to 25 percent of quota

(SDR 4.7 million). Fund financing is expected to partly offset the balance of payments impact from both floods, estimated at US\$46 million, at a time when Belize's official reserves are relatively low (2 months of imports).

- The last Article IV consultation was concluded by the Executive Board on February 22, 2008. At that time, Directors welcomed the improvement in Belize's near-term macroeconomic prospects, supported by oil discoveries, progress in structural reforms, and the debt restructuring agreement completed in February 2007. Directors noted, however, that continued consolidation of public sector finances was needed to address risks to Belize's growth and financial stability.

- Belize has accepted the obligations of Article VIII, Sections 2, 3, and 4. It maintains an exchange system free of restrictions on the making of payments and transfers for current international transactions. The Belize dollar has been pegged to the U.S. dollar since 1976.

- Staff consultation with the authorities was conducted during the last staff visit (November 11-17, 2008) and in subsequent communications from headquarters. 


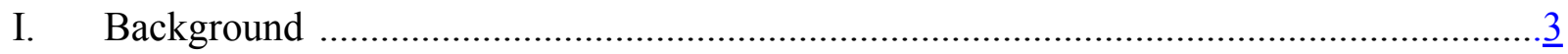

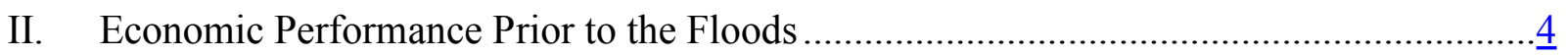

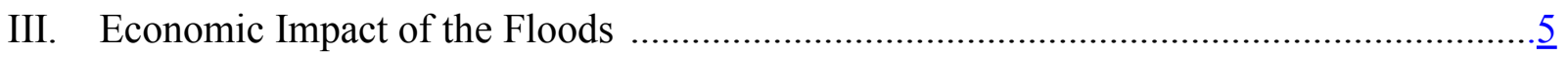

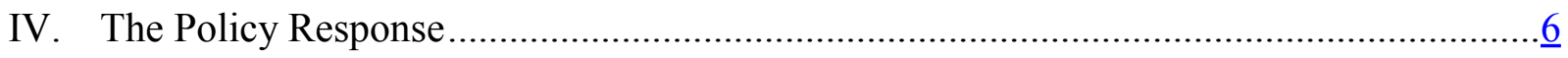

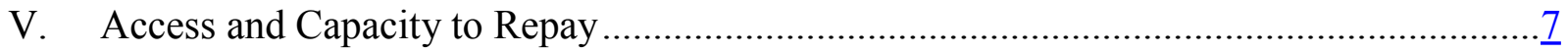

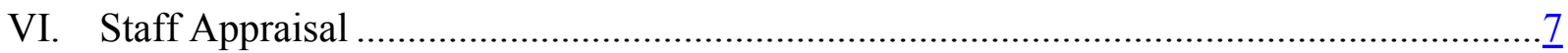

Figures

1a. Public Debt Sustainability: Bound Tests …………....................................................

1b. External Debt Sustainability: Bound Tests ....................................................................19

Tables

1. Selected Economic Indicators, 2004-09 …….................................................................

2a. Operations of the Central Government, 2007-10 …….............................................

2b. Operations of the Central Government, 2007-10 ………............................................

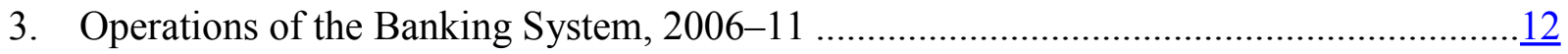

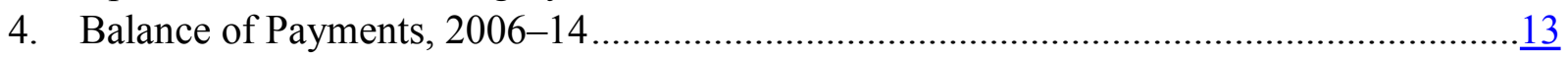

5. Financial and External Vulnerability Indicators, 2004-08 ………………………........

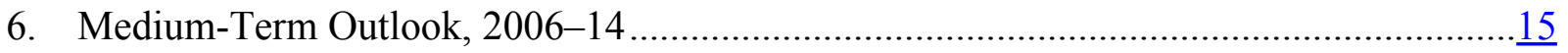

7a. Public Sector Debt Sustainability Framework, 2003-13 ……………………………......

7b. External Debt Sustainability Framework, 2003-13 …………………............................

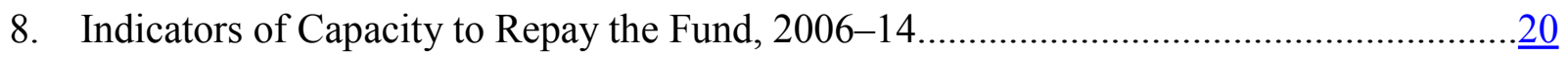

Appendix

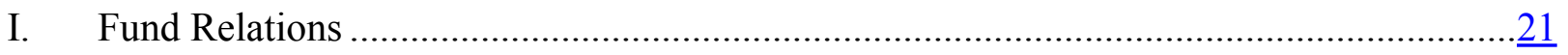

Attachment

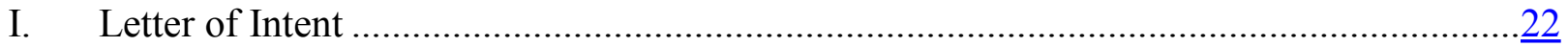




\section{BACKGROUND}

1. Belize suffered considerable destruction from floods resulting from tropical rain systems in May-June and October 2008. The weather system culminating in Tropical Storm Arthur made a landfall on May 28 in Nicaragua. Through the first week of June, total rainfall in Belize reached nearly 30 inches, resulting in extensive flooding in the Corozal, Orange Walk, and Stann Creek Districts. Tropical Depression No. 16 (TD-16) made landfall in northern Honduras on October 16, 2008 inundating the highland region of Central America with rain for about five consecutive days. The situation was exacerbated a few days later by strong rainfall in Southern Mexico. Within days, the water masses moved from the Cayo highlands eastward into the Belize River Valley, and from the Mexican border Southward, to the lower-lying regions of central and Northern Belize, flooding over 100 communities in the Eastern Cayo, Belize, Orange Walk, and Corozal Districts. Flood waters began to recede only in November. The overall direct and economic losses are estimated at about US\$66 million (4.8 percent of GDP), and the balance of payments impact at US\$46 million.

2. The government promptly provided emergency assistance to the population in the regions affected by the disaster. The floods affected 50,000 people, or roughly onesixth of Belize's population. The government of Belize, through the National Emergency Management Organization (NEMO), has distributed food, clean water, medical care, and other emergency relief supplies to about 16,500 people in the affected areas.

\section{The authorities have requested a purchase equivalent to 25 percent of quota} (SDR 4.7 million) under the Fund's policy on Emergency Assistance for Natural Disasters (ENDA). In the attached letter, Prime Minister Barrow describes the harm caused by the floods to the Belizean people, physical infrastructure, and the economy, including the country's balance of payments. He also explains his government's macroeconomic policies for the period ahead. The Fund's emergency assistance will bolster Belize's external reserves which are being affected by increased imports and shortfalls in export earnings resulting from the floods (see below), at a time when deteriorating global conditions are expected to adversely affect the country's external accounts.

4. The international community is also providing assistance. The CDB has already approved two infrastructure support loans of US $\$ 9$ million to rebuild bridges destroyed by Tropical Storm Arthur. Belize has also requested additional assistance from the CDB (US\$10 million) and from the IDB (US\$5 million) for infrastructure projects, largely in the flood areas affected by TD-16. The International Red Cross, PAHO, UNICEF, UNDP, and USAID provided emergency grants (US\$0.5 million), food items, and medical and technical assistance. 


\section{Economic Performance Prior to the Floods}

5. In recent years, economic growth has been sustained largely by rising oil production, while inflation has remained under control. Despite rising oil production, economic growth was low in 2007 (1.2 percent), in part because of the impact of Hurricane Dean. In 2008, growth is estimated to have remained low (21/2 percent), reflecting the impact of floods on economic activity. Rising food and fuel prices pushed 12-month inflation to $9 \frac{1}{2}$ percent last summer, but it declined to $4 \frac{1}{2}$ percent by November.

6. Boosted by external grants, the primary surplus of the central government is projected to increase from $3 \frac{3}{4}$ percent of GDP in 2007/08 to $4 \frac{3}{4}$ percent in FY2008/09. With nominal stocks broadly unchanged, total public debt declined to about 80 percent of GDP by end-2008. However, the underlying fiscal position is weaker as recurrent expenditure has been growing rapidly, at a time of rising dependence on volatile revenue sources, such as petroleum and grants.

7. The external current account deficit widened sharply to 13 percent of GDP in 2008, largely reflecting a surge in FDI-related imports. These increases in private inflows and associated imports are not expected to be sustained, in particular in the context of the global slowdown. The gross international reserves of the Central Bank of Belize (CBB) reached US\$166 million (2 months of imports) by end-2008. Some of this recent increase, however, reflects external disbursements deposited by the government with the CBB, which will be spent during 2009 as agreed with donors.

8. The impact of the global slowdown on Belize appears to have been limited thus far. The authorities are confident that the banking system is stable and adequately capitalized, and largely insulated from international market turmoil. The first amortization payment on the private debt restructured in early 2007 will fall due only in 2019. However, external reserves at the $\mathrm{CBB}$ remain low and the economy is expected to be adversely affected by the impact of the global slowdown on tourism, FDI, and remittances, as well as by the lasting effect of the recent floods. Belize's commodity exports (mainly crude oil, citrus, fisheries, banana, sugar) will be affected by lower international prices and tourist arrivals will decline reflecting income and wealth effects of the global slowdown impacting Belize's main partner countries.

\section{Progress in the structural reform agenda continues, but significant challenges} persist. In the area of tax administration, domestic revenue collection is being computerized and the ASYCUDA system, to be rolled in the coming months, is expected to strengthen the customs department and enhance audit procedures. A paper outlining next steps in reforming monetary management will be submitted shortly for the consideration by the government. A review of public expenditure and financial accountability supported by the European Union is being finalized, setting out a reform agenda. The authorities are aware of the pressing need 
to strengthen the financial position of key public sector programs, in particular with regard to the Social Security Board and the pension plan for civil servants, in order to ensure the longterm viability of public finances.

\section{ECONOMIC IMPACT OF THE FLOODS}

\section{According to a preliminary assessment by NEMO, the damage to output and} infrastructure from the two floods reached 4.8 percent of GDP. The damage to agriculture, which ruined the crops of bananas, corn, papaya, and sugarcane, was substantial, with additional secondary impact on other sectors of the economy. Tourism was also adversely affected, as many tourist destinations, including those for cruise ship passenger day-tours, were flooded or could not be accessed by road, and had to be temporarily closed. Losses to infrastructure were also significant. Flood waters undermined roads and destroyed or weakened bridges. More than 1,700 buildings were inundated, destroying private household items and private and public housing infrastructure.

\section{The fiscal impact of the floods is expected to be mostly in the form of additional} spending on emergency relief and reconstruction. Revenue performance has been on target, underpinned by robust tax collections, in particular from the sales tax and petroleum extraction. The authorities have reallocated investment and additional spending to assist the affected population and rehabilitate vital infrastructure, estimated at US\$30 million (2.2 percent of GDP). A significant share of additional spending on infrastructure rehabilitation will extend into FY 2009/10, and will be reflected in the next year's budget.

12. The balance of payments impact of the two floods is estimated at US\$46 million (3.3 percent of GDP). The external current account position will be affected by losses in exports of agricultural goods and tourism receipts, as well as increased imports of food and inputs for agriculture and infrastructure rehabilitation. Most of the export losses, conservatively estimated at the cost of destroyed unprocessed export crops, took place during 2008 and were mainly in the citrus and banana sectors. By contrast, losses in the sugar sector will be principally reflected in lower exports in 2009. On the import side, about two thirds of the impact will be from higher imports of reconstruction-related materials, and most of the remainder for agricultural inputs, which is expected to take place in 2009. Imports will also be affected by slower economic activity and lower international prices. The combined impact of the floods over the 2008-09 period is equivalent to nearly one third of end-2008 external foreign reserves. 


\begin{tabular}{|c|c|c|c|c|c|}
\hline & \multirow[b]{2}{*}{2007} & $\begin{array}{l}\text { Before } \\
\text { Floods }\end{array}$ & $\begin{array}{c}\text { After } \\
\text { Floods }\end{array}$ & $\begin{array}{l}\text { Before } \\
\text { Floods }\end{array}$ & $\begin{array}{r}\text { After } \\
\text { Floods }\end{array}$ \\
\hline & & \multicolumn{2}{|c|}{2008 Est. } & \multicolumn{2}{|c|}{2009 Proj. } \\
\hline External current account balance & -51.1 & -165.9 & -179.2 & -62.0 & -94.8 \\
\hline Exports of goods and services & 823.7 & 864.8 & 851.5 & 848.1 & 842.7 \\
\hline Imports of goods and services & -810.2 & -977.4 & -977.4 & -866.5 & -893.9 \\
\hline
\end{tabular}

IV. The Policy Response

13. After focusing on emergency relief, the authorities are now concentrating their efforts on infrastructure rehabilitation and measures to restart economic activity in the affected areas. Assessment of the repair needs to critical infrastructure is being conducted with the support of the $\mathrm{CDB}$ and the IDB, which are in the process of preparing their financial assistance. The government has allocated about US\$6 million from its own resources for infrastructure rehabilitation during 2009. In the context of the budget preparation for FY 2009/10, the government has indicated that it will review its ongoing investment program to incorporate the additional flood relief spending in a manner consistent with medium-term debt sustainability.

\section{The authorities have reaffirmed their commitment to pursuing prudent fiscal} policies. As stated in the attached letter, the government is committed to a fiscal strategy aimed at reducing the debt ratio significantly over the medium term, maintaining price stability, and increasing Belize's external reserves. They recognize that Belize's public debt burden remains high, which limits the fiscal space for addressing the consequences of exogenous shocks. They are also aware of a growing dependence of the budget on volatile revenue sources such as petroleum and grants. Therefore, they intend to consider appropriate policy adjustments while broadly following the fiscal strategy outlined in the context of last year's Article IV consultation. The authorities have also indicated that they welcome the opportunity to discuss their fiscal strategy and needed policy adjustments in the context of the forthcoming 2009 Article IV consultation.

\section{The authorities remain committed to fiscal structural reforms to boost revenues} and strengthen the viability of public finances. Further improvements in tax administration, including more transparency and regular audits of oil taxation, are key priorities. The authorities recognize the need to develop a strategy for contingent public liabilities. The pension plan for civil servants will require additional annual budget contributions for the next decade and the Social Security Board needs to be reformed to regain a sound financial footing. Benefits coverage and participant contributions under both plans may need to be adjusted to restore financial viability. The roll-out of the National Health Insurance is being delayed pending agreement on how to achieve sustainable funding. The authorities also indicated that the Development Finance Corporation will resume its 
lending operations in the coming months, with funding from the CDB, and that appropriate safeguards will be in place to ensure financial viability and avoid risks to the budget.

\section{AcCess And Capacity To Repay}

\section{The authorities have requested a purchase for an amount equivalent to} SDR 4.7 million (25 percent of quota) under the Fund's policy of ENDA. The purchasewhich represents approximately 0.5 percent of Belize's 2008 GDP_-would help meet the immediate foreign exchange needs stemming from the floods, thereby reducing a decline in Belize's external reserves, which remain low relative to imports and external debt service.

\section{It is expected that Belize will be able to discharge its obligations to the Fund in a} timely manner. Belize's public sector and external debt was on a declining trajectory before the tropical systems of 2008, largely reflecting improvements in the fiscal primary balance since 2005. Belize is also benefiting from a significant cash-flow relief obtained in the cooperative debt restructuring agreement concluded with external private creditors in 2007 . This agreement resulted in a 21 percent NPV reduction in the external debt owed to private creditors.

\section{Belize's public debt is expected to remain on a declining path, but debt-related} risks have increased in the deteriorating global environment. Belize remains vulnerable to exogenous shocks, as its public debt burden is high and external debt service obligations are set to increase in two steps in 2010 and 2012, when the coupon rate on the private restructured debt reaches 8.5 percent, up from 4.5 percent currently. In addition, external reserves would remain low (Table 4) under unchanged policies (the authorities' commitment to increase them is reassuring in this regard). This will overlap with the period of repurchases under the ENDA falling due in 2012-14. However, in the staff's view the risks to the Fund are mitigated by the authorities' commitment to prudent fiscal and monetary policies and to maintaining macroeconomic stability.

\section{Staff Appraisal}

\section{Belize's economy has suffered significant losses from the tropical systems and} the resulting floods during 2008. Economic growth in 2008 was reduced by the floods that paralyzed economic activity in large parts of the country for weeks. In addition, Belize's imports will increase to provide inputs to agriculture and for repairs to damaged infrastructure. The medium-term outlook remains positive, but considerable efforts and resources are needed to rebuild productive capacity to the levels prior to the floods, particularly in the agricultural sector which is important for growth and exports. Belize is also facing higher investment needs to repair damaged public infrastructure, at a time of tight budgetary resources and limited international reserves. 
20. The staff believes that policies outlined in the letter of intent are adequate for sustaining fiscal consolidation and maintaining broad macroeconomic stability. The authorities rightly seek to address the reconstruction effort through financial assistance from multilateral institutions on relatively favorable terms and the reallocation of public investment, cognizant of the large public debt. The staff welcomes the opportunity to review the authorities' fiscal strategy in the context of the forthcoming Article IV consultation discussions, and in particular to take into account a significant deterioration in the global environment. The authorities' fiscal strategy will need to target primary surpluses consistent with improving debt sustainability within a framework of sound macroeconomic policies and structural reforms aimed at achieving high and sustainable growth over the medium term.

\section{The staff supports the authorities' request for a purchase under the Fund's} policy on emergency assistance for natural disasters. In the staff's view, the authorities' request is justified on the basis of the considerable damage to the economy and associated balance of payment needs, in the context of low international reserves. Belize's large public debt and a relatively high vulnerability to exogenous shocks could pose some risks to the Fund's resources. Nonetheless, these risks, in staff view, are mitigated to a large degree by the soundness of policies outlined in the attached letter of intent, the expectation of continued support from the international community, and the authorities' commitment to work closely with the Fund in developing the medium-term fiscal strategy to improve debt sustainability. The staff welcomes the authorities' commitment to stay current in all debt-service payments to creditors and not to impose or intensify restrictions on the making of payments and transfers for current international transactions, introduce multiple currency practices, nor impose or intensify import restrictions for balance of payments purposes, or conclude bilateral payments' agreements that are inconsistent with Article VIII. 
Table 1. Belize: Selected Economic Indicators, 2004-09

\begin{tabular}{|c|c|c|c|c|c|c|}
\hline & 2004 & 2005 & 2006 & 2007 & $\begin{array}{r}\text { Est. } \\
2008\end{array}$ & $\begin{array}{l}\text { Proj. } \\
2009\end{array}$ \\
\hline & \multicolumn{6}{|c|}{ (Annual percentage change, unless otherwise indicated) } \\
\hline \multicolumn{7}{|l|}{ National income and prices } \\
\hline GDP at constant prices & 4.6 & 3.0 & 4.7 & 1.2 & 2.5 & 2.0 \\
\hline GDP deflator & 2.2 & 2.4 & 4.0 & 4.0 & 5.0 & 2.5 \\
\hline Consumer prices (end of period) & 3.1 & 4.2 & 2.9 & 4.1 & 4.4 & 2.5 \\
\hline Gross domestic investment 1/ 2/ & 18.9 & 21.6 & 17.7 & 16.9 & 26.9 & 21.3 \\
\hline Gross national savings $1 /$ & 4.2 & 8.0 & 15.6 & 12.9 & 13.8 & 14.7 \\
\hline \multicolumn{7}{|l|}{ External sector } \\
\hline Exports of goods and services & 3.0 & 15.3 & 26.0 & 4.3 & 3.4 & -1.0 \\
\hline Imports of goods and services & -5.1 & 13.9 & 6.9 & 6.0 & 20.6 & -8.5 \\
\hline Terms of trade (deterioration -) & -2.5 & -5.9 & -1.2 & 2.0 & 2.3 & -3.3 \\
\hline Nominal effective exchange rate & -0.5 & 0.2 & 1.2 & -0.7 & 2.1 & $\ldots$ \\
\hline Real effective exchange rate & -2.4 & -1.3 & 0.9 & -2.8 & 0.5 & $\ldots$ \\
\hline \multicolumn{7}{|l|}{ Money and credit } \\
\hline Credit to the private sector & 9.6 & 11.3 & 13.1 & 13.9 & 11.0 & 7.1 \\
\hline Money and quasi-money (M2) & 7.5 & 5.9 & 17.3 & 22.5 & 11.0 & 3.9 \\
\hline \multirow[t]{2}{*}{ Weighted average lending rates (in percent) } & 14.0 & 14.3 & 14.2 & 14.2 & 14.1 & $\ldots$ \\
\hline & \multicolumn{6}{|c|}{ (In percent of GDP) } \\
\hline \multicolumn{7}{|l|}{ Central government 3 / } \\
\hline Revenue and grants & 22.8 & 23.4 & 25.3 & 27.4 & 29.4 & 27.7 \\
\hline Of which: oil & 0.0 & 0.0 & 0.5 & 2.2 & 1.8 & 2.0 \\
\hline grants & 1.5 & 0.6 & 1.4 & 1.1 & 3.0 & 1.8 \\
\hline Current expenditure & 22.6 & 24.7 & 22.9 & 23.3 & 23.4 & 22.9 \\
\hline Capital expenditure and net lending & 6.5 & 4.1 & 4.4 & 5.1 & 5.7 & 5.9 \\
\hline Primary balance & 0.8 & 2.1 & 3.8 & 3.9 & 4.5 & 2.3 \\
\hline Overall balance & -6.4 & -5.4 & -2.0 & -1.1 & 0.3 & -1.1 \\
\hline \multicolumn{7}{|l|}{ External sector } \\
\hline External current account $4 /$ & -14.7 & -13.6 & -2.1 & -4.0 & -13.0 & -6.6 \\
\hline Public and publicly guaranteed debt & 100.1 & 98.4 & 92.2 & 88.6 & 79.6 & 77.3 \\
\hline Domestic debt & 9.0 & 7.3 & 8.3 & 9.0 & 7.8 & 7.5 \\
\hline External debt & 91.1 & 90.9 & 83.9 & 79.5 & 71.9 & 69.8 \\
\hline Debt service $5 / 6 /$ & 21.5 & 20.1 & 10.5 & 9.9 & 7.9 & 6.3 \\
\hline In percent of exports of goods and services & 43.6 & 36.6 & 16.2 & 15.3 & 12.7 & 10.8 \\
\hline \multirow[t]{2}{*}{ In percent of government current revenue } & 106.0 & 90.7 & 44.7 & 39.1 & 30.2 & 24.7 \\
\hline & \multicolumn{6}{|c|}{ (In millions of U.S. dollars, unless otherwise specified) } \\
\hline Overall balance of payments & -31 & -12 & 50 & 23 & 61 & -24 \\
\hline Exports of goods and services & 544 & 627 & 790 & 824 & 852 & 843 \\
\hline Imports of goods and services & 628 & 715 & 764 & 810 & 977 & 894 \\
\hline Gross usable official reserves & 48 & 71 & 104 & 109 & 166 & 149 \\
\hline In percent of projected 12-month external public debt service & 21 & 56 & 16 & 101 & 182 & 153 \\
\hline In months of imports & 0.9 & 1.2 & 1.6 & 1.6 & 2.0 & 2.0 \\
\hline Nominal GDP & 1,056 & 1,115 & 1,213 & 1,277 & 1,374 & 1,437 \\
\hline
\end{tabular}

Sources: Belize authorities; and Fund staff estimates and projections.

$1 /$ In percent of GDP.

2/ Including inventory accumulation.

3/ Calendar year.

4/ Including official grants.

5/ Public and publicly guaranteed external debt.

6/ Excluding amortization and interest payments of the debt exchange operation in 2007. 
Table 2a. Belize: Operations of the Central Government, 2007-10 1/

\begin{tabular}{|c|c|c|c|c|}
\hline & $\begin{array}{l}\text { Outturn } \\
2007 / 08\end{array}$ & $\begin{array}{r}\text { Approved } \\
\text { Budget } \\
2008 / 09\end{array}$ & $\begin{array}{r}\text { Staff } \\
\text { Proj. } \\
2008 / 09\end{array}$ & $\begin{array}{r}\text { Staff } \\
\text { Proj. } \\
2009 / 10\end{array}$ \\
\hline Revenue and grants & 720 & 825 & 839 & 783 \\
\hline Revenue & 695 & 738 & 739 & 748 \\
\hline Current revenue & 665 & 729 & 730 & 739 \\
\hline Tax revenue & 592 & 637 & 642 & 659 \\
\hline Of which: petroleum operations & 25 & 40 & 34 & 40 \\
\hline Of which: sales tax & 175 & 180 & 182 & 190 \\
\hline Nontax revenue & 73 & 92 & 88 & 80 \\
\hline Of which: petroleum operations & 11 & 25 & 19 & 20 \\
\hline Capital revenue and debt service receipts & 30 & 9 & 9 & 9 \\
\hline Grants & 25 & 87 & 100 & 35 \\
\hline Expenditure & 736 & 825 & 821 & 858 \\
\hline Current expenditure & 599 & 650 & 658 & 685 \\
\hline Wages and salaries & 234 & 263 & 260 & 273 \\
\hline Pensions & 42 & 40 & 46 & 48 \\
\hline Goods and services & 126 & 162 & 162 & 165 \\
\hline Interest payments, fees, and charges & 113 & 109 & 115 & 120 \\
\hline Transfers & 83 & 76 & 75 & 79 \\
\hline Capital expenditure and net lending & 137 & 175 & 163 & 173 \\
\hline Capital expenditure & 134 & 172 & 160 & 170 \\
\hline Domestically financed expenditure (Capital II) & 72 & 79 & 85 & 70 \\
\hline Foreign financed expenditure (Capital III) & 62 & 93 & 75 & 100 \\
\hline Net lending & 3 & 3 & 3 & 3 \\
\hline Primary balance & 98 & 109 & 133 & 45 \\
\hline Overall balance & -16 & 0 & 18 & -75 \\
\hline Financing & 16 & 0 & -18 & 75 \\
\hline Domestic & 23 & 0 & -32 & 20 \\
\hline External & -29 & -29 & 14 & 32 \\
\hline Disbursements & 151 & 35 & 78 & 97 \\
\hline \multicolumn{5}{|l|}{ Memorandum items: } \\
\hline Nominal GDP (in BZ\$ millions) & 2,602 & 2,686 & 2,779 & 2,908 \\
\hline Non-interest expenditure & 622 & 716 & 706 & 738 \\
\hline Budgeted oil revenue & 36 & 65 & 53 & 60 \\
\hline Oil revenue & 36 & 65 & 53 & 60 \\
\hline
\end{tabular}

Sources: Ministry of Finance; Central Bank of Belize; and Fund staff estimates and projections.

1/ Fiscal year end-March. 
Table 2b. Belize: Operations of the Central Government, 2007-10 1/

\begin{tabular}{|c|c|c|c|c|}
\hline & $\begin{array}{l}\text { Outturn } \\
2007 / 08\end{array}$ & $\begin{array}{l}\text { Approved } \\
\text { Budget } \\
2008 / 09\end{array}$ & $\begin{array}{r}\text { Staff } \\
\text { Proj. } \\
2008 / 09\end{array}$ & $\begin{array}{r}\text { Staff } \\
\text { Proj. } \\
2009 / 10\end{array}$ \\
\hline Revenue and grants & 27.7 & 30.7 & 30.2 & 26.9 \\
\hline Revenue & 26.7 & 27.5 & 26.5 & 25.7 \\
\hline Non-oil revenue & 25.3 & 25.0 & 24.7 & 23.7 \\
\hline Current revenue & 25.5 & 27.1 & 26.2 & 25.4 \\
\hline Tax revenue & 22.7 & 23.7 & 23.0 & 22.7 \\
\hline Of which: sales tax & 6.7 & 6.7 & 6.5 & 6.5 \\
\hline Nontax revenue & 2.8 & 3.4 & 3.2 & 2.8 \\
\hline Capital revenue and debt service receipts & 1.2 & 0.3 & 0.3 & 0.3 \\
\hline Grants & 1.0 & 3.3 & 3.6 & 1.2 \\
\hline Expenditure & 28.3 & 30.7 & 29.5 & 29.5 \\
\hline Current expenditure & 23.0 & 24.2 & 23.7 & 23.6 \\
\hline Wages and salaries & 9.0 & 9.8 & 9.4 & 9.4 \\
\hline Pensions & 1.6 & 1.5 & 1.7 & 1.7 \\
\hline Goods and services & 4.8 & 6.0 & 5.8 & 5.7 \\
\hline Interest payments, fees, and charges & 4.4 & 4.1 & 4.1 & 4.1 \\
\hline Transfers & 3.2 & 2.8 & 2.7 & 2.7 \\
\hline Capital expenditure and net lending & 5.3 & 6.5 & 5.9 & 5.9 \\
\hline Capital expenditure & 5.1 & 6.4 & 5.8 & 5.8 \\
\hline Domestically financed expenditure (Capital II) & 2.8 & 2.9 & 3.1 & 2.4 \\
\hline Foreign financed expenditure (Capital III) & 2.4 & 3.5 & 2.7 & 3.4 \\
\hline Net lending & 0.1 & 0.1 & 0.1 & 0.1 \\
\hline Primary balance & 3.8 & 4.1 & 4.8 & 1.6 \\
\hline Non-oil, nongrant primary balance & 1.4 & -1.6 & -0.7 & -1.7 \\
\hline Overall balance & -0.6 & 0 & 0.6 & -2.6 \\
\hline Financing & 0.6 & 0.0 & -0.6 & 2.6 \\
\hline \multicolumn{5}{|l|}{ Memorandum items: } \\
\hline Nominal GDP (in BZ\$ millions) & 2,602 & 2,686 & 2,779 & 2,908 \\
\hline Non-interest expenditure & 23.9 & 26.7 & 25.4 & 25.4 \\
\hline Budgeted oil revenue (in percent of GDP) & 1.4 & 2.4 & 1.9 & 2.1 \\
\hline Oil revenue (in percent of GDP) & 1.4 & 2.4 & 1.9 & 2.1 \\
\hline
\end{tabular}

Sources: Ministry of Finance; Central Bank of Belize; and Fund staff estimates and projections.

1/ Fiscal year end-March. 
Table 3. Belize: Operations of the Banking System, 2006-11

\begin{tabular}{|c|c|c|c|c|c|c|}
\hline & & & Est. & & Proj. & \\
\hline & 2006 & 2007 & $2008^{-7}$ & 2009 & 2010 & 2011 \\
\hline & \multicolumn{6}{|c|}{ (In millions of Belize dollars) } \\
\hline \multicolumn{7}{|l|}{ Central Bank of Belize (CBB) } \\
\hline Net foreign assets $1 /$ & 206 & 215 & 330 & 297 & 296 & 305 \\
\hline Net international reserves & 206 & 215 & 330 & 297 & 296 & 305 \\
\hline Medium-term foreign liabilities & 0 & 0 & 0 & 0 & 0 & 0 \\
\hline Net domestic assets & 115 & 121 & 29 & 77 & 92 & 98 \\
\hline Credit to the public sector (net) & 144 & 148 & 53 & 100 & 115 & 122 \\
\hline Central government & 179 & 184 & 85 & 134 & 150 & 157 \\
\hline Other nonfinancial public sector & -35 & -37 & -32 & -33 & -34 & -35 \\
\hline Claims on commercial banks & 0 & 0 & 0 & 0 & 0 & 0 \\
\hline Capital and other assets (net) & -29 & -26 & -23 & -23 & -24 & -24 \\
\hline Base money & 321 & 336 & 359 & 373 & 388 & 403 \\
\hline Currency issue & 169 & 186 & 179 & 198 & 206 & 213 \\
\hline Reserves of commercial banks & 152 & 150 & 180 & 175 & 182 & 189 \\
\hline \multicolumn{7}{|l|}{ Commercial banks } \\
\hline Net foreign assets & 65 & 136 & 70 & 75 & 96 & 117 \\
\hline Net claims on central bank & 185 & 183 & 210 & 219 & 227 & 236 \\
\hline Net domestic assets & 1,341 & 1,528 & 1,718 & 1,821 & 1,897 & 1,968 \\
\hline Credit to the public sector (net) & -48 & -55 & -42 & -91 & -109 & -118 \\
\hline Central government & 23 & 47 & 97 & 50 & 34 & 26 \\
\hline Other nonfinancial public sector & -71 & -102 & -139 & -141 & -143 & -145 \\
\hline Credit to the private sector & 1,528 & 1,740 & 1,932 & 2,069 & 2,163 & 2,244 \\
\hline Other assets (net) & -139 & -157 & -172 & -157 & -157 & -157 \\
\hline Liabilities to the private sector & 1,590 & 1,847 & 1,998 & 2,115 & 2,219 & 2,321 \\
\hline \multicolumn{7}{|l|}{ Monetary survey } \\
\hline Net foreign assets & 271 & 351 & 403 & 372 & 392 & 422 \\
\hline Net domestic assets & 1,456 & 1,649 & 1,744 & 1,898 & 1,988 & 2,066 \\
\hline Public sector (net) & 96 & 92 & 11 & 9 & 6 & 3 \\
\hline Central government & 202 & 231 & 182 & 183 & 183 & 183 \\
\hline Other nonfinancial public sector & -106 & -138 & -171 & -174 & -177 & -180 \\
\hline Credit to private sector (by comm. banks) & 1,528 & 1,740 & 1,932 & 2,069 & 2,163 & 2,244 \\
\hline Other items (net) & -168 & -184 & -199 & -181 & -181 & -181 \\
\hline Liabilities to the private sector & 1,728 & 2,000 & 2,147 & 2,270 & 2,380 & 2,488 \\
\hline Money and quasi-money (M2) & 1,338 & 1,539 & 1,729 & 1,797 & 1,867 & 1,939 \\
\hline Currency in circulation & 137 & 153 & 149 & 155 & 161 & 167 \\
\hline Deposits & 1,201 & 1,386 & 1,580 & 1,642 & 1,706 & 1,772 \\
\hline Foreign currency deposits & 68 & 79 & 50 & 68 & 68 & 68 \\
\hline Capital and reserves of commercial banks & 321 & 382 & 368 & 404 & 445 & 480 \\
\hline & \multicolumn{6}{|c|}{ (In millions of U.S. dollars) } \\
\hline Net international reserves of the CBB & 103 & 108 & 165 & 148 & 148 & 153 \\
\hline & \multicolumn{6}{|c|}{ (In percent change, unless otherwise indicated) } \\
\hline \multicolumn{7}{|l|}{ Memorandum items: } \\
\hline Comm. bank credit to the private sector & 13.1 & 13.9 & 11.0 & 7.1 & 4.5 & 3.7 \\
\hline Private sector deposits in local currency & 17.3 & 15.4 & 14.0 & 3.9 & 3.9 & 3.9 \\
\hline Base money & 25.9 & 4.6 & 6.8 & 3.9 & 3.9 & 3.9 \\
\hline Money and quasi-money (M2) & 17.3 & 22.5 & 11.0 & 3.9 & 3.9 & 3.9 \\
\hline Required cash reserve ratio (percent) & 10.0 & 10.0 & 10.0 & 10.0 & 10.0 & 10.0 \\
\hline Velocity (M2) & 1.81 & 1.66 & 1.59 & 1.60 & 1.61 & 1.63 \\
\hline Loan deposit ratio & 120.4 & 118.8 & 118.5 & 121.0 & 121.9 & 121.9 \\
\hline
\end{tabular}

Sources: The Central Bank of Belize; and Fund staff estimates and projections.

$1 /$ Includes Central Government's foreign assets. 
Table 4. Belize: Balance of Payments, 2006-14

\begin{tabular}{|c|c|c|c|c|c|c|c|c|c|}
\hline \multirow[b]{4}{*}{ Current account balance } & \multirow[b]{2}{*}{2006} & \multirow[b]{2}{*}{2007} & \multirow[b]{2}{*}{2008} & \multicolumn{6}{|c|}{ Proj. } \\
\hline & & & & 2009 & 2010 & 2011 & 2012 & 2013 & 2014 \\
\hline & \multicolumn{9}{|c|}{ (In millions of U.S. dollars) } \\
\hline & -25 & -51 & -179 & -95 & -77 & -82 & -82 & -93 & -102 \\
\hline Trade balance & -185 & -216 & -349 & -245 & -269 & -266 & -296 & -316 & -334 \\
\hline Total exports, f.o.b. & 427 & 426 & 460 & 445 & 496 & 512 & 511 & 528 & 545 \\
\hline \multicolumn{10}{|l|}{ Of which: } \\
\hline Oil & 39 & 64 & 101 & 70 & 76 & 74 & 68 & 63 & 58 \\
\hline Total imports, fob & -612 & -642 & -809 & -690 & -765 & -777 & -807 & -844 & -880 \\
\hline \multicolumn{10}{|l|}{ Of which: } \\
\hline Fuel and lubricants & -99 & -102 & -127 & -68 & -84 & -92 & -97 & -102 & -107 \\
\hline Services & 211 & 230 & 223 & 194 & 237 & 262 & 309 & 331 & 348 \\
\hline Income & -125 & -158 & -178 & -139 & -135 & -170 & -188 & -203 & -212 \\
\hline \multicolumn{10}{|l|}{ Of which: } \\
\hline Public sector interest payments & -67 & -59 & -45 & -46 & -52 & -62 & -74 & -84 & -89 \\
\hline Current transfers & 74 & 93 & 124 & 96 & 90 & 92 & 93 & 95 & 97 \\
\hline Private (net) & 65 & 78 & 84 & 70 & 80 & 82 & 83 & 85 & 87 \\
\hline Official (net) & 8 & 16 & 41 & 26 & 10 & 10 & 10 & 10 & 10 \\
\hline Capital and financial account balance & 83 & 102 & 256 & 71 & 77 & 87 & 88 & 104 & 112 \\
\hline Capital transfers & 9 & 4 & 8 & 6 & 1 & 1 & 1 & 1 & 1 \\
\hline Public sector & 17 & 16 & -14 & 6 & 15 & 25 & 25 & 40 & 47 \\
\hline \multicolumn{10}{|l|}{ Of which: } \\
\hline Change in assets & 0 & 0 & 0 & 0 & 0 & 0 & 0 & 0 & 0 \\
\hline Change in liabilities 1) & 17 & 16 & -12 & 6 & 15 & 25 & 25 & 40 & 47 \\
\hline Disbursements & 84 & 77 & 40 & 51 & 61 & 65 & 62 & 76 & 87 \\
\hline Central government & 84 & 77 & 38 & 49 & 60 & 64 & 62 & 76 & 87 \\
\hline Amortization & -66 & -62 & -52 & -45 & -45 & -40 & -37 & -36 & -39 \\
\hline Central government & -61 & -62 & -42 & -33 & -26 & -29 & -28 & -31 & -35 \\
\hline Private sector $2 /$ & 57 & 82 & 263 & 60 & 61 & 61 & 62 & 63 & 64 \\
\hline Errors and omissions & -8 & -28 & -16 & 0 & 0 & 0 & 0 & 0 & 0 \\
\hline Overall balance & 50 & 23 & 61 & -24 & 0 & 4 & 6 & 11 & 10 \\
\hline \multicolumn{10}{|l|}{ Financing } \\
\hline Change in reserves (- increase) & -50 & -23 & -61 & 24 & 0 & -4 & -6 & -11 & -10 \\
\hline & \multicolumn{9}{|c|}{ (In percent of GDP, unless otherwise stated) } \\
\hline \multicolumn{10}{|l|}{ Memorandum items: } \\
\hline Gross international reserves (US\$ millions) & 104 & 109 & 166 & 142 & 142 & 146 & 153 & 164 & 174 \\
\hline Months of imports & 1.3 & 1.6 & 2.0 & 2.0 & 1.9 & 1.9 & 1.9 & 1.9 & 1.9 \\
\hline Current account balance & -2.1 & -4.0 & -13.0 & -6.6 & -5.1 & -5.2 & -4.9 & -5.3 & -5.6 \\
\hline Merchandise trade balance & -15.2 & -17.0 & -25.4 & -17.1 & -17.8 & -16.8 & -17.9 & -18.1 & -18.3 \\
\hline Capital and financial account balance & 6.9 & 8.0 & 18.6 & 4.9 & 5.1 & 5.5 & 5.3 & 6.0 & 6.1 \\
\hline Private sector & 4.8 & 6.5 & 19.2 & 4.2 & 4.1 & 3.9 & 3.8 & 3.7 & 3.5 \\
\hline Public sector & 2.1 & 1.5 & -0.5 & 0.5 & 1.0 & 1.6 & 1.5 & 2.3 & 2.6 \\
\hline Overall balance & 4.1 & 1.8 & 4.4 & -1.7 & 0.0 & 0.3 & 0.4 & 0.7 & 0.6 \\
\hline
\end{tabular}

Sources: Central Bank of Belize; and Fund staff estimates and projections.

1/ Disbursements and amortization are net of the debt exchange operation in 2007.

2/ Detailed data on private sector flows are not available. 
Table 5. Belize: Financial and External Vulnerability Indicators, 2004-08

(In percent of GDP, unless otherwise indicated)

\begin{tabular}{|c|c|c|c|c|c|}
\hline & 2004 & 2005 & 2006 & 2007 & $\begin{array}{r}\text { Est. } \\
2008\end{array}$ \\
\hline \multicolumn{6}{|l|}{ Financial indicators } \\
\hline Broad money (percent change) & 7.5 & 5.9 & 17.3 & 22.5 & 11.0 \\
\hline Private sector credit & 9.6 & 11.3 & 13.1 & 13.9 & 11.0 \\
\hline Adversely classified loans/total loans (in percent) $1 /$ & 6.0 & 8.7 & 6.2 & 6.8 & 8.7 \\
\hline Provision for loan losses/total loans (in percent) $1 /$ & 2.2 & 2.0 & 2.2 & 2.2 & 2.8 \\
\hline Total capital/risk-weighted assets (in percent) 1/ & 17.5 & 18.4 & 21.4 & 22.9 & 19.1 \\
\hline Tier 1 capital/risk-weighted assets (in percent) $1 /$ & 16.3 & 17.5 & 20.4 & 21.6 & 18.0 \\
\hline Net profit before taxes/average assets (in percent) $1 /$ & 4.9 & 4.3 & 4.1 & 3.9 & 3.6 \\
\hline Three-month treasury bill rate & 3.3 & 3.3 & 3.3 & 3.3 & 3.3 \\
\hline Three-month treasury bill rate (real) $2 /$ & 0.2 & -0.9 & 0.3 & -0.8 & -1.2 \\
\hline \multicolumn{6}{|l|}{ External indicators } \\
\hline Exports of goods and services (percent change, U.S. dollars basis) & 3.0 & 15.3 & 26.0 & 4.3 & 3.4 \\
\hline Imports of goods and services (percent change, U.S. dollars basis) & -5.1 & 13.9 & 6.9 & 6.0 & 20.6 \\
\hline Current account balance & -14.7 & -13.6 & -2.1 & -4.0 & -13.0 \\
\hline Capital and financial account balance & 12.0 & 13.2 & 6.9 & 8.0 & 18.6 \\
\hline Gross official reserves (US\$ million) & 48.0 & 71.3 & 104.4 & 108.8 & 165.8 \\
\hline In percent of broad money & 8.9 & 12.5 & 15.6 & 14.1 & 19.2 \\
\hline In months of imports of goods and services & 0.9 & 1.2 & 1.6 & 1.6 & 2.0 \\
\hline In percent of external public debt service due in the following year & 20.9 & 55.8 & 15.8 & 100.9 & 181.9 \\
\hline Public sector external debt & 91.1 & 90.9 & 83.9 & 79.5 & 71.9 \\
\hline External public debt in percent of exports of goods and services & 177.0 & 161.6 & 128.8 & 123.3 & 116.0 \\
\hline Public debt service in percent of exports of goods and services $3 /$ & 43.6 & 36.6 & 16.2 & 15.3 & 12.7 \\
\hline External interest payments to exports of goods and nonfactor services & 11.5 & 11.3 & 8.5 & 7.8 & 6.3 \\
\hline External amortization payments to exports of goods and nonfactor services & 30.3 & 24.5 & 7.7 & 72.6 & 6.3 \\
\hline Exchange rate (per U.S. dollar) & 2.0 & 2.0 & 2.0 & 2.0 & 2.0 \\
\hline REER appreciation (average of period; - depreciation) & -2.4 & -1.3 & 0.9 & -2.8 & 0.5 \\
\hline
\end{tabular}

Sources: Central Bank of Belize, Ministry of Finance; and Fund staff estimates.

1/ Data for 2008 is for the period ending in Sep.

2/ Treasury bill rate adjusted by end-of-period inflation.

3/ Excluding amortization and interest payments of the debt exchange operation in 2007. 
Table 6. Belize: Medium-Term Outlook, 2006-14

\begin{tabular}{|c|c|c|c|c|c|c|c|c|c|}
\hline & \multirow[b]{2}{*}{2006} & \multirow[b]{2}{*}{2007} & \multirow[b]{2}{*}{2008} & \multicolumn{6}{|c|}{ Proj. } \\
\hline & & & & 2009 & 2010 & 2011 & 2012 & 2013 & 2014 \\
\hline & \multicolumn{9}{|c|}{ (Annual percentage change) } \\
\hline \multicolumn{10}{|l|}{ Real economy } \\
\hline GDP at constant prices & 4.7 & 1.2 & 2.5 & 2.0 & 2.3 & 2.3 & 2.4 & 2.5 & 2.5 \\
\hline GDP at current market prices & 8.8 & 5.2 & 7.6 & 4.5 & 4.9 & 4.9 & 5.0 & 5.1 & 5.0 \\
\hline Prices (GDP deflator) & 4.0 & 4.0 & 5.0 & 2.5 & 2.5 & 2.5 & 2.5 & 2.5 & 2.5 \\
\hline & \multicolumn{9}{|c|}{ (In percent of GDP, unless otherwise indicated) } \\
\hline \multicolumn{10}{|l|}{ National accounts } \\
\hline Consumption & 80.2 & 82.1 & 82.3 & 82.3 & 82.1 & 82.1 & 82.0 & 82.0 & 82.0 \\
\hline Gross domestic investment & 17.7 & 16.9 & 26.9 & 21.3 & 20.0 & 18.1 & 17.2 & 17.2 & 17.2 \\
\hline Net exports & 2.1 & 1.1 & -9.2 & -3.6 & -2.1 & -0.2 & 0.7 & 0.9 & 0.8 \\
\hline Gross national savings & 15.6 & 12.9 & 13.8 & 14.7 & 14.9 & 12.9 & 12.3 & 11.9 & 11.7 \\
\hline \multicolumn{10}{|l|}{ Central government $1 /$} \\
\hline Revenue and grants & 25.3 & 27.4 & 29.4 & 27.7 & 26.7 & 26.6 & 26.3 & 26.0 & 25.8 \\
\hline Of which: oil revenue & 0.5 & 2.6 & 1.8 & 2.0 & 2.1 & 2.0 & 1.8 & 1.5 & 1.3 \\
\hline Total expenditure & 27.3 & 28.5 & 29.1 & 28.9 & 28.9 & 28.8 & 28.3 & 28.6 & 28.6 \\
\hline Noninterest expenditure & 21.5 & 23.5 & 24.9 & 25.4 & 25.2 & 24.7 & 23.7 & 23.7 & 23.6 \\
\hline Primary balance & 3.8 & 3.9 & 4.5 & 2.3 & 1.5 & 1.9 & 2.6 & 2.4 & 2.2 \\
\hline Interest & 5.8 & 5.0 & 4.2 & 3.5 & 3.7 & 4.1 & 4.6 & 5.0 & 5.0 \\
\hline Overall balance & -2.0 & -1.1 & 0.3 & -1.1 & -2.3 & -2.2 & -2.0 & -2.6 & -2.8 \\
\hline \multicolumn{10}{|l|}{ External sector } \\
\hline Current account balance & -2.1 & -4.0 & -13.0 & -6.6 & -5.1 & -5.2 & -4.9 & -5.3 & -5.6 \\
\hline Of which: exports of goods and services & 65.1 & 64.5 & 62.0 & 58.7 & 62.0 & 62.3 & 61.8 & 61.5 & 61.5 \\
\hline Of which: petroleum exports & 3.2 & 5.0 & 7.4 & 4.9 & 5.0 & 4.7 & 4.1 & 3.6 & 3.2 \\
\hline Of which: imports of goods and services & -63.0 & -63.5 & -71.1 & -62.2 & -64.1 & -62.5 & -61.1 & -60.7 & -60.8 \\
\hline Capital and financial account & 6.9 & 8.0 & 18.6 & 4.9 & 5.1 & 5.5 & 5.3 & 6.0 & 6.1 \\
\hline Public sector disbursements $2 /$ & 6.9 & 6.1 & 2.9 & 3.5 & 4.0 & 4.1 & 3.7 & 4.4 & 4.7 \\
\hline Public sector amortization 2/ & -5.5 & -4.8 & -3.8 & -3.1 & -3.0 & -2.5 & -2.2 & -2.1 & -2.1 \\
\hline Other capital and fin. account transactions $3 /$ & 5.4 & 6.8 & 19.5 & 4.6 & 4.1 & 3.9 & 3.8 & 3.7 & 3.5 \\
\hline Change in reserves (- increase) & -4.1 & -1.8 & -4.4 & 1.2 & 0.0 & -0.3 & -0.2 & -0.4 & -0.5 \\
\hline Gross official reserves (in months of imports) & 1.6 & 1.6 & 2.0 & 2.0 & 1.9 & 1.9 & 1.9 & 1.9 & 1.9 \\
\hline Public and publicly guaranteed debt & 92.2 & 88.6 & 79.6 & 77.3 & 76.0 & 74.7 & 73.1 & 72.2 & 71.6 \\
\hline Domestic & 8.3 & 9.0 & 7.8 & 7.5 & 7.1 & 6.8 & 6.5 & 6.2 & 5.9 \\
\hline External & 83.9 & 79.5 & 71.9 & 69.8 & 68.8 & 67.9 & 66.7 & 66.0 & 65.7 \\
\hline
\end{tabular}

Source: Fund staff projections.

1/ Fiscal projections are on a calendar year basis.

2/ Disbursements and amortization exclude the gross flows of the debt exchange operation in 2007.

$3 /$ Includes errors and omissions. 
Table 7a. Belize: Public Sector Debt Sustainability Framework, 2003-2013

(In percent of GDP, unless otherwise indicated)

\begin{tabular}{|c|c|c|c|c|c|c|c|c|c|c|c|c|}
\hline & \multicolumn{5}{|c|}{ Actual } & \multicolumn{6}{|c|}{ Projections } & \multirow{3}{*}{$\begin{array}{c}\text { Debt-stabilizing } \\
\text { primary } \\
\text { balance } 9 /\end{array}$} \\
\hline & 2003 & 2004 & 2005 & 2006 & 2007 & 2008 & 2009 & 2010 & 2011 & 2012 & 2013 & \\
\hline & & & & & & & & & & & & \\
\hline $\begin{array}{l}\text { Baseline: Public sector debt 1/ } \\
\text { Of which: foreign-currency denominated }\end{array}$ & $\begin{array}{r}102.3 \\
96.7\end{array}$ & $\begin{array}{l}99.5 \\
91.2\end{array}$ & $\begin{array}{l}98.7 \\
90.8\end{array}$ & $\begin{array}{l}92.1 \\
83.8\end{array}$ & $\begin{array}{l}88.5 \\
79.5\end{array}$ & $\begin{array}{l}79.6 \\
71.9\end{array}$ & $\begin{array}{l}77.3 \\
69.8\end{array}$ & $\begin{array}{l}76.0 \\
68.8\end{array}$ & $\begin{array}{l}74.7 \\
67.9\end{array}$ & $\begin{array}{l}73.1 \\
66.7\end{array}$ & $\begin{array}{l}72.2 \\
66.0\end{array}$ & 1.6 \\
\hline Change in public sector debt & 13.3 & -2.8 & -0.8 & -6.5 & -3.6 & -8.9 & -2.3 & -1.3 & -1.3 & -1.5 & -1.0 & \\
\hline Identified debt-creating flows $(4+7+12)$ & 0.3 & -10.7 & -4.5 & -6.4 & -4.3 & -6.6 & -2.3 & -1.3 & -1.3 & -1.5 & -1.0 & \\
\hline Primary deficit & 5.9 & -0.8 & -1.2 & -3.8 & -3.9 & -4.5 & -2.3 & -1.5 & -1.9 & -2.6 & -2.4 & \\
\hline Revenue and grants & 21.4 & 22.8 & 23.4 & 25.3 & 27.4 & 29.4 & 27.7 & 26.7 & 26.6 & 26.3 & 26.0 & \\
\hline Primary (noninterest) expenditure & 27.3 & 22.0 & 22.2 & 21.5 & 23.5 & 24.9 & 25.4 & 25.2 & 24.7 & 23.7 & 23.7 & \\
\hline Automatic debt dynamics $2 /$ & -0.2 & 0.6 & 0.5 & -2.2 & -0.4 & -2.1 & 0.0 & 0.2 & 0.6 & 1.1 & 1.4 & \\
\hline Contribution from interest rate/growth differential $3 /$ & -0.2 & 0.6 & 0.5 & -2.2 & -0.4 & -2.1 & 0.0 & 0.2 & 0.6 & 1.1 & 1.4 & \\
\hline Of which: contribution from real interest rate & 7.5 & 5.0 & 4.1 & 2.9 & 0.6 & 0.0 & 1.5 & 1.9 & 2.2 & 2.8 & 3.2 & \\
\hline Of which: contribution from real GDP growth & -7.7 & -4.4 & -3.6 & -5.1 & -1.0 & -2.1 & -1.5 & -1.7 & -1.7 & -1.7 & -1.7 & \\
\hline Contribution from exchange rate depreciation $4 /$ & 0.0 & 0.0 & 0.0 & 0.0 & 0.0 & $\ldots$ & $\ldots$ & $\ldots$ & & & $\ldots$ & \\
\hline Other identified debt-creating flows & -5.4 & -10.6 & -3.8 & -0.4 & 0.0 & 0.0 & 0.0 & 0.0 & 0.0 & 0.0 & 0.0 & \\
\hline Privatization receipts (negative) & 4.1 & -1.9 & -2.3 & -0.4 & 0.0 & 0.0 & 0.0 & 0.0 & 0.0 & 0.0 & 0.0 & \\
\hline Recognition of implicit or contingent liabilities & 0.0 & 0.0 & 0.0 & 0.0 & 0.0 & 0.0 & 0.0 & 0.0 & 0.0 & 0.0 & 0.0 & \\
\hline Other (specify, e.g., bank recapitalization) & -9.5 & -8.6 & -1.6 & 0.0 & 0.0 & 0.0 & 0.0 & 0.0 & 0.0 & 0.0 & 0.0 & \\
\hline Residual, including asset changes (2-3) 5/ & 13.0 & 7.9 & 3.7 & -0.2 & 0.7 & -2.3 & 0.0 & 0.0 & 0.0 & 0.0 & 0.0 & \\
\hline Public sector debt-to-revenue ratio $1 /$ & 478.5 & 436.5 & 421.6 & 364.5 & 323.6 & 270.5 & 278.7 & 285.0 & 281.2 & 278.0 & 277.2 & \\
\hline $\begin{array}{l}\text { Gross financing need } 6 / \\
\text { in billions of } U S \text { dollars }\end{array}$ & $\begin{array}{r}15.7 \\
0.7\end{array}$ & $\begin{array}{r}18.2 \\
02\end{array}$ & $\begin{array}{r}19.4 \\
0.2\end{array}$ & 7.0 & 5.1 & 2.7 & 3.4 & 4.0 & 4.1 & 3.7 & 4.4 & \\
\hline Scenario with key variables at their historical averages $?$ & & & & & & 79.6 & 80.2 & 80.8 & 81.4 & 82.0 & 82.5 & -1.3 \\
\hline Scenario with no policy change (constant primary balance) in -2013 & & & & & & 79.6 & 77.3 & 76.0 & 74.7 & 73.1 & 72.2 & 1.6 \\
\hline \multicolumn{13}{|l|}{ Key Macroeconomic and Fiscal Assumptions Underlying Baseline } \\
\hline Real GDP growth (in percent) & 9.2 & 4.6 & 3.9 & 5.6 & 1.2 & 2.5 & 2.0 & 2.3 & 2.3 & 2.4 & 2.5 & \\
\hline Average nominal interest rate on public debt (in percent) $8 /$ & 5.5 & 7.5 & 7.0 & 6.4 & 5.7 & 5.1 & 4.5 & 5.1 & 5.7 & 6.5 & 7.1 & \\
\hline Average real interest rate (nominal rate minus change in GDP deflator, in percent) & 8.6 & 5.4 & 4.5 & 3.3 & 0.8 & 0.1 & 2.0 & 2.6 & 3.2 & 4.0 & 4.6 & \\
\hline Nominal appreciation (increase in US dollar value of local currency, in percent) & 0.0 & 0.0 & 0.0 & 0.0 & 0.0 & $\ldots$ & $\ldots$ & & & & $\ldots$ & \\
\hline Inflation rate (GDP deflator, in percent) & -3.1 & 2.1 & 2.5 & 3.1 & 4.9 & 5.0 & 2.5 & 2.5 & 2.5 & 2.5 & 2.5 & \\
\hline Growth of real primary spending (deflated by GDP deflator, in percent) & 7.7 & -15.6 & 4.1 & 2.2 & 9.5 & 8.7 & 3.9 & 1.4 & 0.4 & -1.7 & 2.3 & \\
\hline Primary deficit & 5.9 & -0.8 & -1.2 & -3.8 & -3.9 & -4.5 & -2.3 & -1.5 & -1.9 & -2.6 & -2.4 & \\
\hline A2. No policy change (constant primary balance) in 2005-09 & & & & & & 79.6 & 77.3 & 76.0 & 74.7 & 73.1 & 72.2 & 1.6 \\
\hline \multicolumn{13}{|l|}{ B. Bound Tests } \\
\hline B1. Real interest rate is at historical average plus one standard deviation & & & & & & 79.6 & 78.2 & 77.7 & 77.2 & 76.6 & 76.5 & 2.3 \\
\hline B2. Real GDP growth is at his & & & & & & 79.6 & 79.1 & 80.0 & 81.4 & 83.0 & 85.8 & 3.2 \\
\hline B3. Primary balance is at historic & & & & & & 79.6 & 79.4 & 80.1 & 81.0 & 81.6 & 82.9 & 1.6 \\
\hline B4. Combination of B1-B3 using 1/2 standard deviation shocks & & & & & & 79.6 & 79.5 & 80.3 & 81.2 & 81.9 & 83.3 & 2.8 \\
\hline B5. One time 30 percent real depreciation in 2006 10/ & & & & & & 79.6 & 111.9 & 110.7 & 109.6 & 108.6 & 108.4 & 2.1 \\
\hline B6. 10 percent of GDP increase in other debt-creating flows in 2006 & & & & & & 79.6 & 87.3 & 86.0 & 84.8 & 83.4 & 82.6 & 1.6 \\
\hline
\end{tabular}

debt includes central government, publicly guaranteed external dob $2 /$ Derived as $[(r-\pi(1+g)-g+\alpha \varepsilon(1+r)](1+g+\pi+g \pi))$ times provar

$3 /$ The real interesst in local contribution is ververved from the delar.

$4 /$ The exchange rate contribution is derived from the numerator in footnote $2 /$ as as $(1+r)$.

TFor projections, this line includes exchange rate changes.

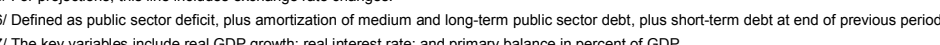

8/ Derived as nominal interest expenditure divided by previous period debt stock

9/ Assumes that key variables (real GDP growth, real interest rate, and other identified debt-creating flows) remain at the level of 2013 to capture the increased interest rates statring from 2013 due to the step-up structure of the exchanged bond.

CInternational Monetary Fund. Not for Redistribution 
Figure 1a. Belize Public Debt Sustainability: Bound Tests 1/ (Public debt in percent of GDP)

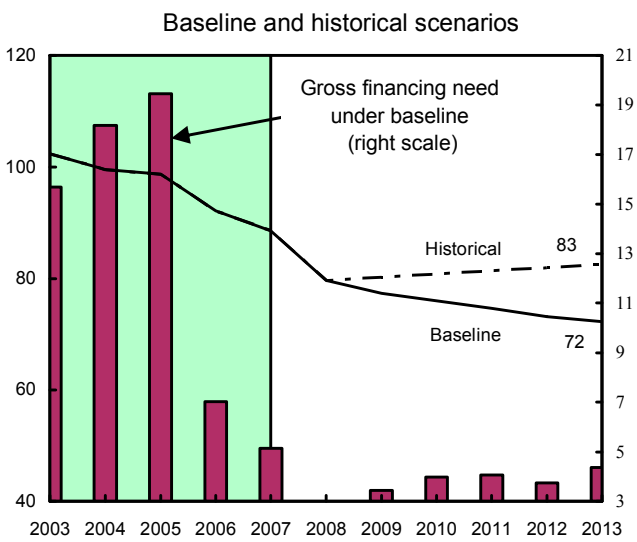

Growth shock (in percent per year)

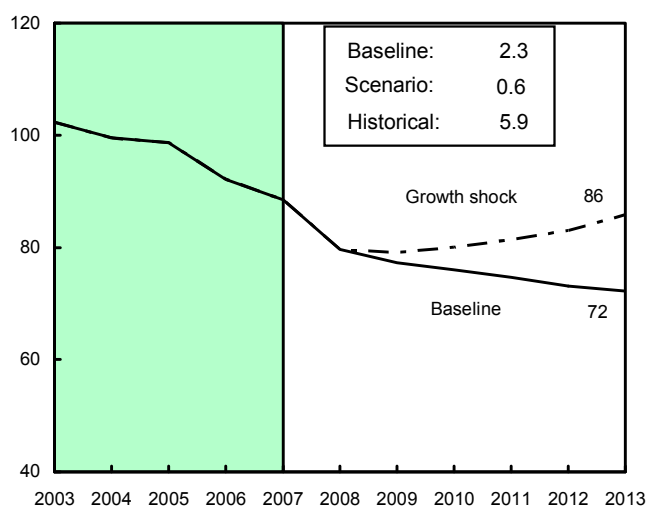

Combined shock $2 /$

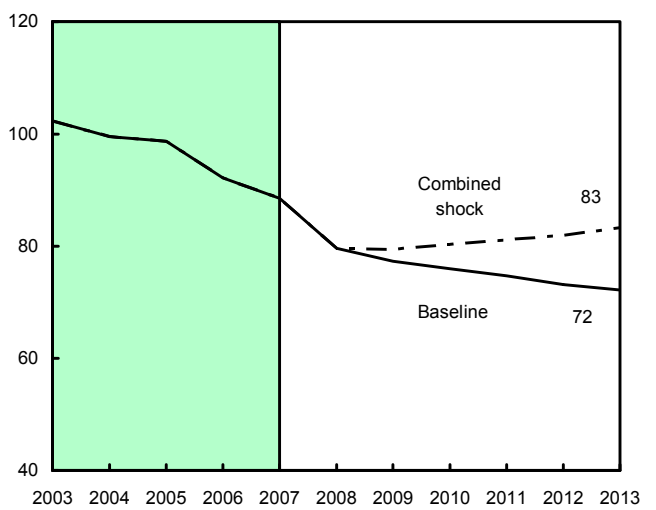

Interest rate shock (in percent)

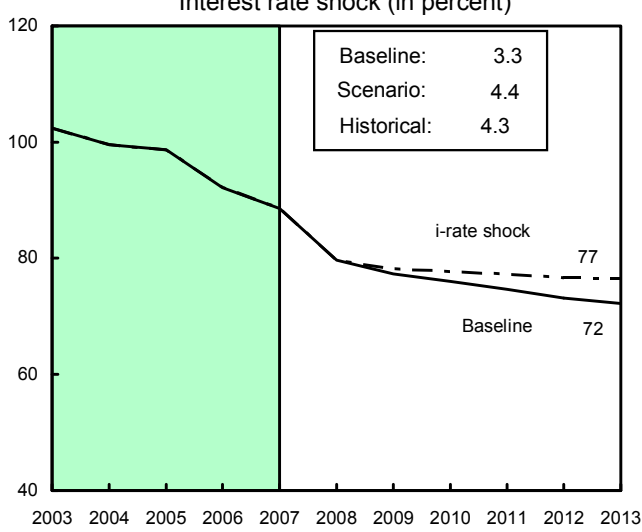

Primary balance shock (in percent of GDP) and no policy change scenario (constant primary balance)

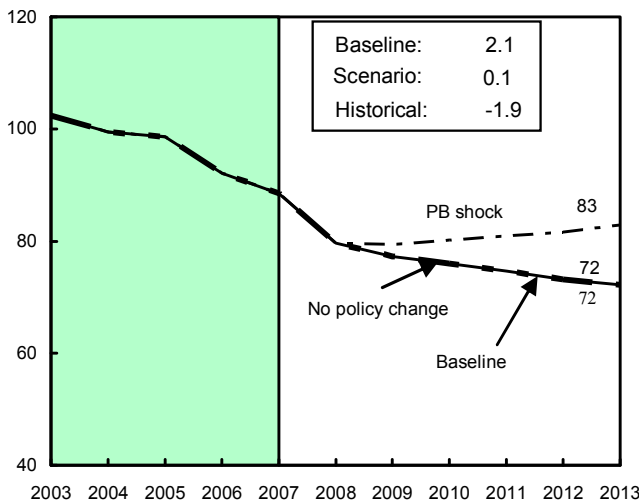

Real depreciation and contingent liabilities shocks 3/

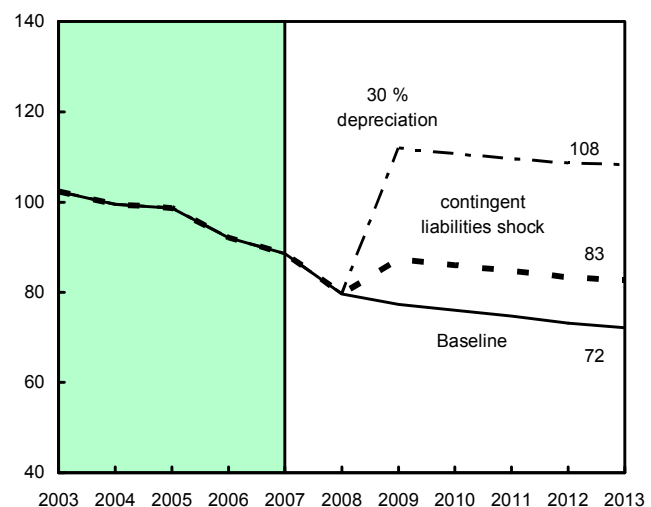

Sources: International Monetary Fund, country desk data, and staff estimates.

$1 /$ Shaded areas represent actual data. Individual shocks are permanent one-half standard deviation shocks. Figures in the boxes represent average projections for the respective variables in the baseline and scenario being presented. Ten-year historical average for the variable is also shown. 2/ Permanent $1 / 4$ standard deviation shocks applied to real interest rate, growth rate, and primary balance.

$3 /$ One-time real depreciation of 30 percent and 10 percent of GDP shock to contingent liabilities occur in 2008 , with real depreciation defined as nominal depreciation (measured by percentage fall in dollar value of local currency) minus domestic inflation (based on GDP deflator). 
Table 7b. Belize: External Debt Sustainability Framework, 2003-2013

(In percent of GDP, unless otherwise indicated)

\begin{tabular}{|c|c|c|c|c|c|c|c|c|c|c|c|c|}
\hline & \multicolumn{5}{|c|}{ Actual } & \multicolumn{7}{|c|}{ Projections } \\
\hline & 2003 & 2004 & 2005 & 2006 & 2007 & 2008 & 2009 & 2010 & 2011 & 2012 & 2013 & Debt-stabilizing \\
\hline Baseline: External debt & 96.7 & 91.2 & 90.8 & 83.8 & 79.5 & 71.9 & 69.8 & 68.8 & 67.9 & 66.7 & 66.0 & $\begin{array}{c}\text { current account } 6 / \\
-2.4\end{array}$ \\
\hline Change in external debt & 10.8 & -5.5 & -0.4 & -7.0 & -4.3 & -7.6 & -2.0 & -1.0 & -1.0 & -1.2 & -0.6 & \\
\hline Identified external debt-creating flows $(4+8+9)$ & 9.7 & -2.7 & -0.8 & -14.1 & -9.8 & -2.7 & 1.1 & -0.5 & -0.2 & -0.4 & 0.1 & \\
\hline Current account deficit, excluding interest payments & 12.4 & 8.5 & 7.6 & -2.8 & -0.3 & 9.5 & 3.7 & 1.9 & 1.7 & 0.8 & 0.8 & \\
\hline Deficit in balance of goods and services & 16.9 & 8.1 & 8.7 & -1.6 & -1.1 & 9.2 & 3.6 & 2.1 & 0.2 & -0.7 & -0.9 & \\
\hline Exports & 50.0 & 51.4 & 55.4 & 64.4 & 64.5 & 62.0 & 58.7 & 62.0 & 62.3 & 61.8 & 61.5 & \\
\hline Imports & 67.0 & 59.5 & 64.1 & 62.8 & 63.5 & 71.1 & 62.2 & 64.1 & 62.5 & 61.1 & 60.7 & \\
\hline Net non-debt creating capital inflows (negative) & -3.7 & -11.3 & -10.3 & -8.7 & -9.6 & -13.9 & -4.2 & -4.0 & -3.9 & -3.7 & -3.6 & \\
\hline Automatic debt dynamics $1 /$ & 1.0 & 0.1 & 1.9 & -2.5 & 0.2 & 1.7 & 1.5 & 1.6 & 2.0 & 2.5 & 2.9 & \\
\hline Contribution from nominal interest rate & 5.8 & 6.3 & 6.8 & 4.9 & 4.3 & 3.6 & 2.9 & 3.2 & 3.6 & 4.1 & 4.5 & \\
\hline Contribution from real GDP growth & -7.4 & -4.2 & -3.3 & -4.7 & -1.0 & -1.8 & -1.4 & -1.5 & -1.5 & -1.6 & -1.6 & \\
\hline Contribution from price and exchange rate changes $2 /$ & 2.6 & -2.0 & -1.5 & -2.7 & -3.2 & $\ldots$ & $\ldots$ & $\ldots$ & $\ldots$ & $\ldots$ & $\ldots$ & \\
\hline Residual, incl. change in gross foreign assets (2-3) 3 / & 1.1 & -2.8 & 0.4 & 7.1 & 5.4 & -4.9 & -3.1 & -0.5 & -0.8 & -0.8 & -0.7 & \\
\hline External debt-to-exports ratio (in percent) & 193.2 & 177.3 & 163.9 & 130.2 & 123.2 & 116.0 & 119.0 & 111.1 & 109.0 & 107.8 & 107.3 & \\
\hline Gross external financing need (in billions of US dollars) $4 /$ & 0.2 & 0.3 & 0.3 & 0.1 & 0.1 & 0.2 & 0.1 & 0.1 & 0.1 & 0.1 & 0.1 & \\
\hline Scenario with key variables at their historical averages 5 / & & & & & & 71.9 & 72.5 & 75.6 & 78.5 & 81.2 & 83.9 & -6.7 \\
\hline \multicolumn{13}{|l|}{ Key Macroeconomic Assumptions Underlying Baseline } \\
\hline Real GDP growth (in percent) & 9.2 & 4.6 & 3.9 & 5.6 & 1.2 & 2.5 & 2.0 & 2.3 & 2.3 & 2.4 & 2.5 & \\
\hline GDP deflator in U.S. dollars (change in percent) & -2.9 & 2.1 & 1.7 & 3.1 & 3.9 & 5.0 & 2.5 & 2.5 & 2.5 & 2.5 & 2.5 & \\
\hline Nominal external interest rate (in percent) & 7.2 & 7.0 & 7.8 & 5.8 & 5.4 & 4.8 & 4.2 & 4.8 & 5.4 & 6.3 & 7.1 & \\
\hline Growth of exports (U.S. dollar terms, in percent) & 0.3 & 9.8 & 13.8 & 26.6 & 5.4 & 3.4 & -1.0 & 10.8 & 5.4 & 4.2 & 4.5 & \\
\hline Growth of imports (U.S. dollar terms, in percent) & 5.2 & -5.1 & 13.9 & 6.6 & 6.3 & 20.6 & -8.5 & 8.0 & 2.3 & 2.6 & 4.3 & \\
\hline Current account balance, excluding interest payments & -12.4 & -8.5 & -7.6 & 2.8 & 0.3 & -9.5 & -3.7 & -1.9 & -1.7 & -0.8 & -0.8 & \\
\hline Net nondebt creating capital inflows & 3.7 & 11.3 & 10.3 & 8.7 & 9.6 & 13.9 & 4.2 & 4.0 & 3.9 & 3.7 & 3.6 & \\
\hline
\end{tabular}

1/ Derived as $[r-g-r(1+g)+e a(1+r)](1+g+r+g r)$ times previous period debt stock, with $r=$ nominal effective interest rate on external debt; $r=$ change in domestic GDP deflator in U.S. dollar terms, $g=$ real GDP growth rate, $e=$ nominal appreciation (increase in dollar value of domestic currency), and alpha = share of domestic-currency denominated debt in total external debt.

$2 /$ The contribution from price and exchange rate changes is defined as $[-r(1+g)+e a(1+r)](1+g+r+g r)$ times previous period debt stock. $r$ increases with an appreciating domestic currency $(e>0)$ and rising inflation (based on GDP deflator).

3/ For projection, line includes the impact of price and exchange rate changes.

4/ Defined as current account deficit, plus amortization on medium- and long-term debt, plus short-term debt at end of previous period.

5/ The key variables include real GDP growth; nominal interest rate; dollar deflator growth; and both non-interest current account and non-debt inflows in percent of GDP.

6/ Long-run, constant balance that stabilizes the debt ratio assuming that key variables (real GDP growth, nominal interest rate, dollar deflator growth, and non-debt inflows in percent of GDP) remain at their levels of the last projection year. 
Figure 1b. Belize: External Debt Sustainability: Bound Tests 1/ (External debt in percent of GDP)

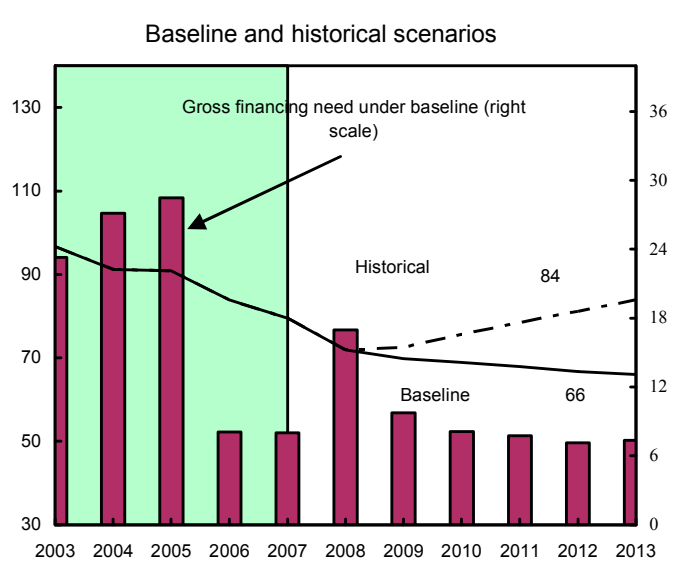

Growth shock (in percent per year)

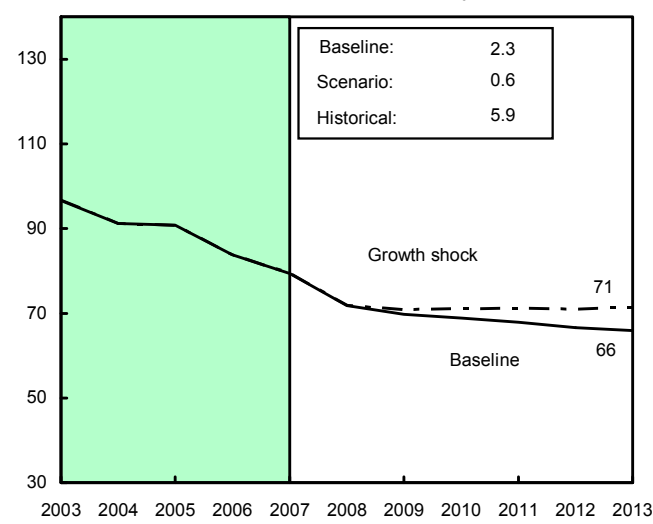

Combined shock 2/

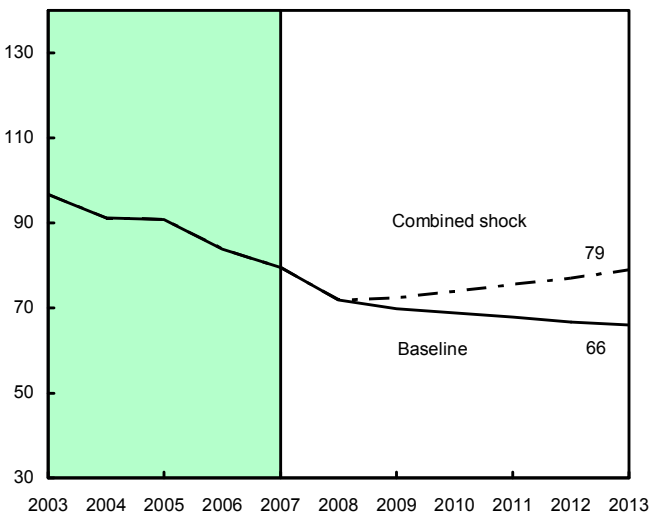

Interest rate shock (in percent)

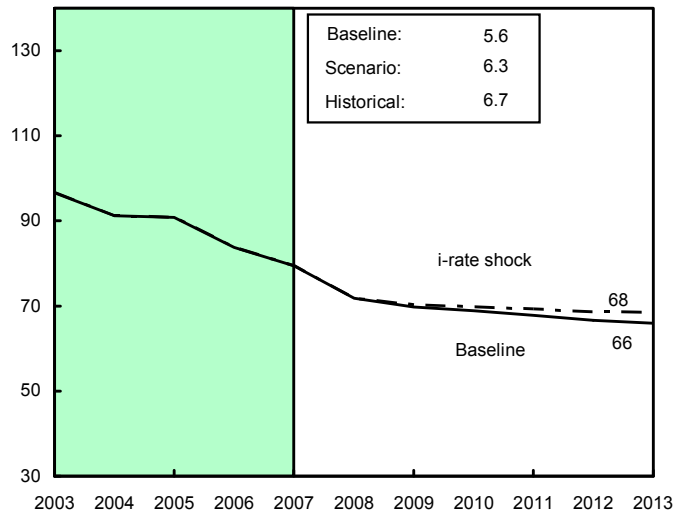

Non-interest current account shock (in percent of GDP)
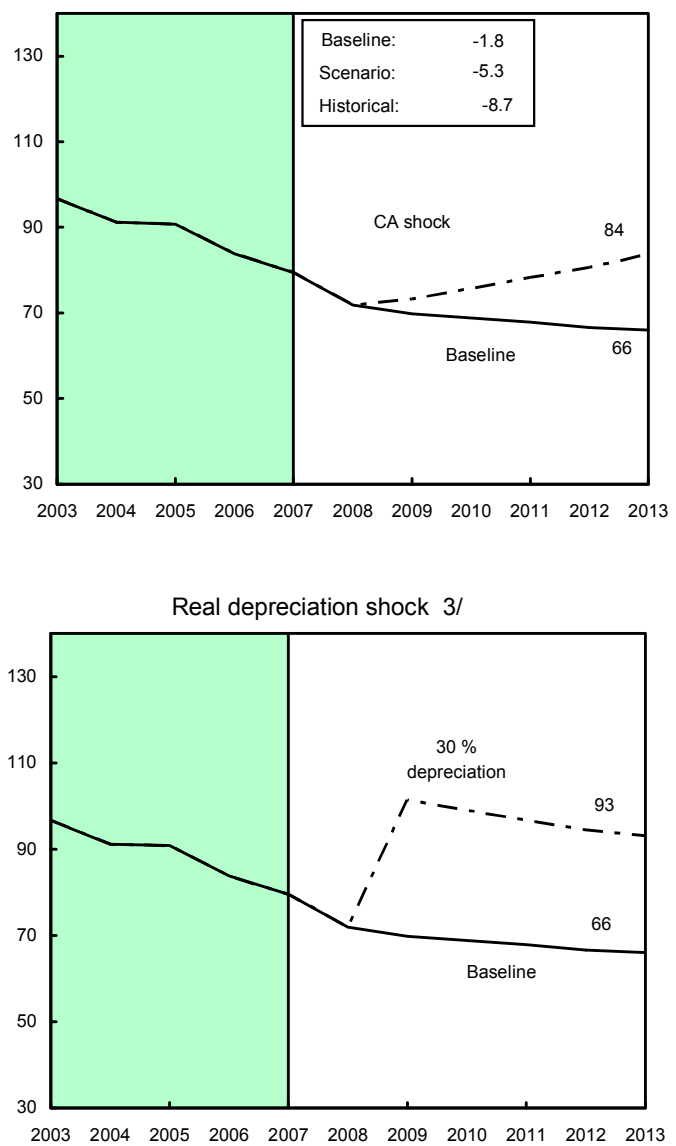

Sources: International Monetary Fund, Country desk data, and staff estimates.

1/ Shaded areas represent actual data. Individual shocks are permanent one-half standard deviation shocks. Figures in the boxes represent average projections for the respective variables in the baseline and scenario being presented. Ten-year historical average for the variable is also shown.

2/ Permanent 1/4 standard deviation shocks applied to real interest rate, growth rate, and current account balance.

3/ One-time real depreciation of 30 percent occurs in 2008. 
Table 8. Belize: Indicators of Capacity to Repay the Fund, 2006-14

(Under obligation schedule)

\begin{tabular}{|c|c|c|c|c|c|c|c|c|c|}
\hline & \multirow[b]{2}{*}{2006} & \multirow[b]{2}{*}{2007} & \multirow[b]{2}{*}{2008} & \multicolumn{6}{|c|}{ Proj. } \\
\hline & & & & 2009 & 2010 & 2011 & 2012 & 2013 & 2014 \\
\hline \multicolumn{10}{|l|}{ Payments from existing drawings } \\
\hline & \multicolumn{9}{|c|}{ (In millions of SDRs) } \\
\hline Principal & 0.0 & 0.0 & 0.0 & 0.0 & 0.0 & 0.0 & 0.0 & 0.0 & 0.0 \\
\hline Charges/interest & 0.0 & 0.0 & 0.0 & 0.0 & 0.0 & 0.0 & 0.0 & 0.0 & 0.0 \\
\hline \multicolumn{10}{|l|}{ Payments from existing and prospective drawings } \\
\hline & \multicolumn{9}{|c|}{ (In millions of SDRs) } \\
\hline Principal $1 /$ & 0.0 & 0.0 & 0.0 & 0.0 & 0.0 & 0.0 & 1.8 & 2.4 & 0.6 \\
\hline Charges/interest & 0.0 & 0.0 & 0.0 & 0.1 & 0.1 & 0.1 & 0.1 & 0.0 & 0.0 \\
\hline \multicolumn{10}{|l|}{ Total outstanding and prospective obligations } \\
\hline In millions of SDRs $1 /$ & 0.0 & 0.0 & 0.0 & 0.1 & 0.1 & 0.1 & 1.9 & 2.4 & 0.6 \\
\hline In millions of USD 2/ & 0.0 & 0.0 & 0.0 & 0.2 & 0.2 & 0.2 & 2.8 & 3.6 & 0.9 \\
\hline In percent of exports of goods and services & 0.0 & 0.0 & 0.0 & 0.0 & 0.0 & 0.0 & 0.0 & 0.0 & 0.0 \\
\hline In percent of debt service & 0.0 & 0.0 & 0.0 & 0.0 & 0.0 & 0.0 & 0.0 & 0.0 & 0.0 \\
\hline In percent of quota & 0.0 & 0.0 & 0.0 & 0.0 & 0.0 & 0.0 & 0.1 & 0.2 & 0.0 \\
\hline In percent of net international reserves & 0.0 & 0.0 & 0.0 & 0.0 & 0.0 & 0.0 & 0.1 & 0.2 & 0.0 \\
\hline \multicolumn{10}{|l|}{ Fund credit outstanding } \\
\hline In millions of SDRs & 0.0 & 0.0 & 0.0 & 4.7 & 4.7 & 4.7 & 2.9 & 0.6 & 0.0 \\
\hline In millions of USD $1 /$ & 0.0 & 0.0 & 0.0 & 7.1 & 7.1 & 7.1 & 4.4 & 0.9 & 0.0 \\
\hline In percent of exports of goods and services & 0.0 & 0.0 & 0.0 & 0.0 & 0.0 & 0.0 & 0.0 & 0.0 & 0.0 \\
\hline In percent of debt service & 0.0 & 0.0 & 0.0 & 0.1 & 0.1 & 0.1 & 0.0 & 0.0 & 0.0 \\
\hline In percent of quota & 0.0 & 0.0 & 0.0 & 0.4 & 0.4 & 0.4 & 0.2 & 0.0 & 0.0 \\
\hline In percent of net international reserves & 0.0 & 0.0 & 0.0 & 0.0 & 0.0 & 0.0 & 0.0 & 0.0 & 0.0 \\
\hline \multicolumn{10}{|l|}{ Memorandum items: } \\
\hline Exports of goods and services (millions of U.S. dollars) & 790.0 & 823.7 & 851.5 & 872.7 & 966.9 & $1,020.4$ & $1,054.1$ & $1,106.7$ & $1,163.1$ \\
\hline Debt service (millions of U.S. dollars) & 140.4 & 681.2 & 107.9 & 91.2 & 97.7 & 101.5 & 110.3 & 119.8 & 128.0 \\
\hline Quota (millions of SDRs) & 18.8 & 18.8 & 18.8 & 18.8 & 18.8 & 18.8 & 18.8 & 18.8 & 18.8 \\
\hline Net international reserves (millions of U.S. dollars) & 103.2 & 107.6 & 165.0 & 148.3 & 148.5 & 153.7 & 150.1 & 155.1 & 163.9 \\
\hline GDP (millions of U.S. dollars) & $1,213.1$ & $1,276.8$ & $1,374.1$ & $1,436.5$ & $1,506.6$ & $1,580.2$ & $1,659.0$ & $1,743.0$ & $1,830.9$ \\
\hline
\end{tabular}

Sources: Belize authorities and Fund staff estimates and projections.

$1 /$ Totals might not add up due to rounding.

$2 / 1$ USD $=0.664029$ SDR (as of Jan 6th 2009). 


\section{ApPENDIX I. Belize-Fund Relations}

(As of January 16, 2009)

I. Membership Status: Joined: March 16, 1982;

$\underline{\text { Article VIII }}$

II. General Resources Account:

SDR Million

Quota

18.80

14.56

\%Quota

100.00

77.46

Reserve Position

4.24

22.55

Holdings Exchange Rate

III. SDR Department:

SDR Million

\%Allocation

Holdings

1.84

N/A

IV. Outstanding Purchases and Loans: None

V. Latest Financial Arrangements:

\begin{tabular}{ccccc} 
Type & $\begin{array}{c}\text { Approval } \\
\text { Date }\end{array}$ & $\begin{array}{c}\text { Expiration } \\
\text { Date }\end{array}$ & $\begin{array}{c}\text { Amount Approved } \\
\text { (SDR Million) }\end{array}$ & $\begin{array}{c}\text { Amount Drawn } \\
\text { (SDR Million) }\end{array}$ \\
\cline { 1 - 1 } Stand-by & Dec 03,1984 & May 31,1986 & 7.13 & 7.13
\end{tabular}

VI. Projected Payments to Fund: None

VII. Implementation of HIPC Initiative: Not Applicable

VIII. Implementation of MDRI Assistance: Not Applicable

\section{B. Nonfinancial Relations}

\section{Exchange Rate}

Since 1976, the Belize dollar has been pegged to the U.S. dollar, the intervention currency, at the rate of BZ\$2 per U.S. dollar. Since the second quarter of 1995, the central bank has been resorting to the rationing of its sales of foreign exchange to commercial banks on an ad-hoc basis, except for some essential import items, which has given rise to restrictions on the making of payments and transfers for current international transactions. 


\section{ATTACHMENT I}

January 23, 2009

Mr. Dominique Strauss-Kahn

Managing Director

International Monetary Fund

$70019^{\text {th }}$ Street, N.W.

Washington, D.C. 20431

Dear Mr. Strauss-Kahn:

Belize has been badly affected by two tropical weather events during the 2008 Hurricane Season. In late May, the southern part of Belize suffered significant damage following the passage of Tropical Storm Arthur. The second event occurred over the period mid-October to early November 2008 when the effects of Tropical Depression 16 (TD 16) caused severe flooding in western and northern Belize, and the Belize River Valley.

Overall, the entire country was affected by torrential rains following the passage of these two tropical storms, which resulted in unprecedented flooding causing loss to human lives and severe damage to the country's infrastructure including the transportation system and income earning sectors. The agricultural sector, in particular sugar cane, corn, papayas, vegetables, rice and bananas, took the brunt of the damage while commercial and residential buildings and other key physical infrastructure were also affected. In the tourism sector, the cottage industries along the Belize River Valley were partially or completely inundated by flood waters. Additionally, tourism earnings were impacted through cancellations and poor access to primary destinations and ancillary facilities. The overall damage is estimated at US\$66 million, 4.8 percent of GDP, and the balance of payments impact at US\$45 million, 3.3 percent of GDP.

Our preliminary estimates suggest that growth in the economy may slow to 1.5 percent in 2009 after 3 years of growth not only as a result of these two natural disasters, but also because of the global economic slowdown. The external current account deficit will remain large as earnings from agricultural exports and tourism revenues fall and rehabilitation and reconstruction imports rise.

The Government moved immediately after these two events to provide relief to those affected by the disasters and repair and reconstruct the damaged homes and dwellings while seeking financing to repair and rehabilitate damaged infrastructure particularly the road network. Donors, including the IDB and CDB, have indicated their willingness to help meet these priorities but the process will require a considerable amount of time and resources. 
Accordingly, the Government of Belize requests a purchase equivalent to SDR 4.7 million (25 percent of quota) under the Fund's Policy on Emergency Assistance for Natural Disasters. The purchase will help meet the foreign exchange needs related to the disaster response, the rise in imports of food, and the replacement of damaged household items, thereby easing pressure on our external reserves and maintaining confidence in the external position.

The Government's overall strategy for dealing with the crisis is mindful of its commitment to implement prudent fiscal and monetary policies that would bring about a reduction of external public debt ratios over the medium term in order to regain market access. We remain committed to fiscal structural reforms to boost revenue and strengthen the viability of public finances. Our monetary policy will continue to aim at maintaining price stability and increasing Belize's international reserves. The first and immediate priority is to provide assistance to those who suffered abrupt losses in earnings and repair critical infrastructure (roads, bridges, drains and culverts). The emergency response has been largely expenditurerelated facilitated in part by the reallocation of previously budgeted capital expenditure of US\$1.5 million and by additional expenditure of US\$4 million to repair and rebuild critical infrastructure, and to assist those who were displaced and/or severely affected by the floods.

The Caribbean Development Bank (CDB) and the Inter-American Development Bank (IDB) have both been approached for emergency reconstruction assistance. The CDB has approved already two loans in the sum of US $\$ 9.3$ million for the reconstruction of two bridges destroyed by Tropical Storm Arthur and for clean-up and restoration to damaged infrastructure. Negotiations are well advanced to access quick-disbursing loans from the CDB (US \$10 million) and the IDB (US \$5 million) to repair the major highway network affected by TD 16. Over the medium-to-long term, we will restore normalcy to the roads and bridges affected by the floods, replace the housing stock, and assist farmers in the rehabilitation of their fields and replacement of livestock lost in the floods.

The government will continue to cooperate with the Fund in an effort to strengthen Belize's balance of payments' situation and maintain economic stability and expect to finalize our medium term and fiscal strategy during the upcoming Article IV Mission scheduled for the latter half of March 2009. The government will stay current in all debt-service payments to creditors and does not intend to impose or intensify restrictions on the making of payments and transfers for current international transactions, introduce multiple currency practices, impose or intensify import restrictions for balance of payments purposes, or conclude bilateral payments' agreements that are inconsistent with Article VIII.

Sincerely yours,

/s/

Dean Oliver Barrow

Prime Minister and Minister of Finance 
Press Release No. 09/41

International Monetary Fund

FOR IMMEDIATE RELEASE

Washington, D.C. 20431 USA

February 18, 2009

\section{IMF Executive Board Approves US\$6.9 Million in Emergency Assistance to Belize}

The Executive Board of the International Monetary Fund (IMF) approved today SDR 4.7 million (about US\$6.9 million) in financing under emergency assistance for natural disasters to support the nation's recovery from the economic after-affects of serious storm damage and flooding in 2008.

Belize sustained considerable damage from flooding, which is estimated to have caused overall direct and economic losses of about US\$66 million, or 4.8 percent of Belize's gross domestic product. The balance of payments impact is estimated at about US\$46 million.

IMF financial support to Belize is part of a range of efforts by the international community to assist the country in its recovery, including infrastructure loans from the Caribbean Development Bank and the Inter-American Development Bank, plus humanitarian aid and technical assistance from UN agencies and international aid groups.

At the conclusion of the Executive Board's discussion of Belize, Mr. Murilo Portugal, Deputy Managing Director and Acting Chair, issued the following statement:

"The IMF extends its deepest sympathy to the people of Belize for the loss of life and extensive damage caused by the tropical storms and the resulting flooding during 2008 , which has resulted in great hardship for many Belizeans. The adverse balance of payments impact of these natural disasters is compounded by falling external demand due to a global downturn.

"Support from the international community, including emergency assistance from the IMF, will be vital to finance needed imports, while preventing international reserves from falling significantly below the present levels. In recent years, Belize has reduced fiscal imbalances, inflation has remained under control, and macroeconomic stability has been preserved. The authorities are committed to prudent fiscal and monetary policies consistent with halving public debt ratios over the medium term. The authorities' medium-term strategy and

Washington, D.C. 20431 • Telephone 202-623-7100 • Fax 202-623-6772 • www.imf.org 
structural reforms to strengthen public sector programs and improve liquidity management will be discussed in the context of the next Article IV consultation in spring 2009.

“The authorities' continued implementation of prudent policies, combined with support from the international community, should help Belize recover from the setbacks caused by the floods and restore the economy's growth potential," Mr. Portugal said.

Belize has been a member of the IMF since March 1982, and its quota is SDR 18.80 million (about US\$27.7 million). 


\section{Statement by Michael Horgan, Executive Director for Belize and Shawn Ladd, Advisor to Executive Director February 18, 2009}

At the outset, my Belizean authorities express their appreciation to Management and the staff for invaluable advice and assistance in dealing with the challenges arising from the recent floods and of improving macroeconomic management. The authorities have explained the situation and their undertakings clearly in the Letter of Intent. They agree with the broad thrust of the staff appraisal and find the policy recommendations consistent with their medium-term reform plans.

\section{Economic Impact of the Floods}

In recent years, the medium-term macroeconomic outlook for Belize had been improving, with the discovery of oil, a successful debt restructuring, and a stronger medium-term fiscal strategy. Nevertheless, debt remains high and foreign exchange reserves low for a small vulnerable country. Belize has not been directly impacted by the global financial market turmoil (the banking system is stable and well-capitalized) but is expected to encounter lower export demand, tourist arrivals, and remittances in the global downturn. The authorities anticipate only 1.5 percent real output growth in 2009 , making them slightly more conservative than the staff, which projects 2.0 percent.

Prime Minister Barrow's letter describes the damage done to Belize by the floods of 2008, in terms of loss of life, damage to physical infrastructure, agricultural output and the balance of payments. Overall damage is estimated at \$66 million, or 4.8 percent of GDP. The staff vividly illustrates the estimated impact on external current account in para. 12 of the staff report: \$13.3 million in 2008 and 32.8 million in 2009, or 3.3 percent of GDP over two years.

\section{The Policy Response}

The authorities remain focused on improving Belize's medium-term fiscal outlook, while dealing with the impact of the flooding with their own resources and with the assistance of multilateral institutions including the Fund. The staff's baseline public-sector and external debt sustainability projections show steadily declining debt ratios. The authorities are now even more pleased with the results of the debt restructuring of 2007; without it, the debt sustainability framework would not be as satisfactory, and there would be even less latitude and fewer resources to contend with the impact of the floods.

The authorities have reallocated planned capital spending to begin to repair and rebuild critical infrastructure affected by the floods. They are grateful for the early response from the Caribbean Development Bank to date, and hope to attract more funding from both the Caribbean Development Bank (\$10 million) and Inter-American Development Bank 
(\$5 million) toward the reconstruction of the major highway network.

\section{The Request}

The emergency assistance that the Fund could provide would make an important contribution to Belize's efforts at this juncture, bolstering international reserves to deal with a significant, but transitory, pressure on the balance of payments. Under the circumstances, the authorities would greatly appreciate a favorable response by the Board to their request for emergency assistance in the amount of 25 percent of their quota.

With this, our Belizean authorities thank Executive Directors for their views and look forward to the 2009 Article IV consultations next month. 